\title{
O patacho Providência, um navio negreiro política, justiça e redes depois da lei antitráfico de 1831*
}

\section{The schooner Providência, a slaveship \\ politics, Justice and networks after the 1831 anti slave trade law}

\author{
MARCUS J. M. DE CARVALHO** \\ Departamento de História \\ Universidade Federal de Pernambuco \\ Recife $(P E)$ \\ Brasil
}

RESUMO O patacho Providência foi capturado pela marinha brasileira em 1839 por ordem direta do presidente da província de Pernambuco. O promotor que indiciou os envolvidos foi Nabuco de Araújo, então um dependente político dos irmãos Cavalcanti e do regente pernambucano Araújo Lima. Pelo menos outros 22 navios negreiros visitaram Pernambuco naquele mesmo ano. Somente o Providência foi capturado. O caso foi julgado pela justiça pernambucana, tendo como juiz um ex-presidente da Paraíba e depois enviado para a comissão mista no Rio de Janeiro, provocando um intenso debate diplomático, envolvendo portugueses, brasileiros e ingleses. Este caso permite observar os meandros da política local e imperial em relação ao tráfico, as redes do tráfico e ainda nos ajuda a entender como

\footnotetext{
Artigo recebido em: 11/10/2013. Aprovado em: 03/06/2014.

http://dx.doi.org/10.1590/S0104-87752014000300009

** Agradeço ao CNPq pelo apoio a esta pesquisa e aos pareceristas da revista Varia-História pela atenta leitura. Contato: marcus.carvalho.ufpe@hotmail.com.
} 
a repressão ou conivência estavam vinculadas às tensões políticas local e imperial em diferentes níveis.

Palavras-chave tráfico de escravos, Regresso de 1837, lei antitráfico de 1831

ABSTRACT The schooner Providência was captured by the Brazilian navy in 1839, by direct order of the President of the province of Pernambuco. The district attorney who prosecuted the slave dealers was Nabuco de Araújo, then a political dependent of the Cavalcanti brothers and the Regent Araújo Lima, also a Pernambucan. There were at least other 22 slave ships that visited Pernambuco in that same year. Only the Providência was captured. The case went to trial at the local justice, in Pernambuco, the judge was a former President of Paraíba, and later sent to the Mixed Commission in Rio de Janeiro, leading to an intense diplomatic debate between Brazil, Portugal and England. This case helps us to observe local and imperial politics regarding the slave trade, the networks of the Atlantic slave trade and also helps us to understand how the repression or connivance to the slave trade were linked to politics in different levels.

Keywords slave trade, the reaction of 1837 , the 1831 anti slave trade law

\section{Introdução}

Estudar o comércio atlântico de escravos depois de 1831 é lidar com histórias mal contadas, com omissões, com os segredos dos que participaram, compactuaram e se beneficiaram. As narrativas contidas nas fontes são muito variadas. Confusas até. O tráfico envolvia desde gente rica a pessoas pobres que trabalhavam no ramo nas funções mais diversas. Fortunas consideráveis foram construídas, mas também havia gente mal paga trabalhando em serviços mais simples e inconstantes. Nos anos finais do tráfico, não foram poucos os que perderam tudo, ou quase isso, ao caírem nas armadilhas dos riscos envolvidos. Foram muitos os navios apreendidos e cada caso é bastante distinto do outro. Todavia, alguns episódios chamam atenção nem tanto por seus detalhes mais sórdidos - onipresentes - mas por questões legais, políticas e diplomáticas que resultaram na produção de fontes preciosas para os historiadores possibilitando um melhor entendimento não apenas do evento em si, a apreensão de um dado navio negreiro, mas também dos agentes envolvidos, das redes do tráfico e das circunstâncias políticas da repressão. A captura e julgamento do Providência é um desses casos.

Vale ressaltar que a natureza judicial e diplomática das fontes consultadas abre ainda uma ampla perspectiva de possibilidades de interpretação, 
pois as partes que falam nessas fontes não têm nenhuma pretensão de neutralidade. Todos defendiam uma posição definida, a favor ou contra, e mentiam, manipulavam e escolhiam somente as provas que lhes interessavam. As narrativas do episódio, portanto, não são unívocas. Por paradoxal que seja, é justamente aí que reside a riqueza da documentação judicial e diplomática: todos são partes interessadas. Se prestarmos atenção no labirinto de argumentos discordantes, podemos ver imensas concordâncias, descrições de circunstâncias e eventos que todas as partes compartilhavam, apesar do litígio em pontos específicos. As pessoas e muitas das circunstâncias são as mesmas nas narrativas que acusam ou defendem os traficantes. O que muda são as justificativas para determinados atos, as motivações dos agentes e o sentido de suas ações. Para o historiador que busca entender como se deu a conquista do Egito e qual o significado disso para o mundo antigo, tanto faz o tamanho do nariz de Cleópatra ou a sinceridade ou não do amor de Marco Antônio. Nas páginas seguintes, vamos tentar articular esse mosaico de narrativas dissonantes para observar melhor as redes e estratégias do tráfico e a atuação da elite imperial diante desse desafio diplomático e judicial, que, em si, também era uma resposta a outro desafio, a tal "ausência de mão de obra" de que tanto se queixavam.

Para guiar melhor a leitura, já que lidaremos com narrativas dissonantes, resumo antecipadamente alguns pontos centrais que serão desenvolvidos no correr do texto.

O navio foi capturado no dia 21 de julho de 1839. Só o fato da apreensão ter sido feita pela marinha brasileira numa época em que o tráfico era feito às claras, é em si um pouco inusitado. Vinte e três negreiros estiveram em Pernambuco naquele ano. Só o Providência foi apreendido. E isso a mando do presidente da província, futuro Conde da Boa Vista e Senador pelo partido conservador. O promotor que abriu o inquérito foi Nabuco de Araújo, futuro ministro de Estado, que na época era dependente político dos Cavalcanti, do Presidente Rego Barros e, naturalmente, do então Regente Araújo Lima. Isso em um momento em que as tensões intraoligárquicas em Pernambuco estavam sendo recosturadas, já que um Cavalcanti, o Hollanda (Cavalcanti), também fora candidato à Regência-Una em 1838, ficando em segundo lugar na votação que consagrou Araújo Lima. As fontes sobre a apreensão do Providência revelam os meandros da tensão intraoligárquica na província e expressa ainda a tensão latente entre o regente Araújo Lima e os saquaremas na corte. O regente cercou-se de sua própria rede clientelar e buscou se impor diante da força econômica e política das lideranças das chamadas "províncias do sul". Dessa tensão, resultou a crise parlamentar que levaria à sua queda no chamado "golpe da maioridade". O Providência foi um episódio nessa disputa e nos ajuda a entende-la, ao detalhar as redes do próprio regente. As fontes sobre esse caso revelam ainda um elemento novo no debate historiográfico sobre o tráfico, que é a 
politização da repressão, que podia ser seletiva, sempre que assim interessasse aos grupos no poder. Pretendo, por último, contribuir para com a historiografia que estuda a dimensão judicial e política do tráfico, o seu impacto nas localidades em que ocorriam os desembarques e as redes do tráfico, mais especificamente as que envolviam os traficantes atuantes em Pernambuco, o terceiro local que mais recebeu gente no Brasil, o quinto nas Américas e, no entanto, ainda relativamente pouco estudado, como bem disseram Eltis e Silva. ${ }^{1}$

\section{O Regresso, o regente, e as redes clientelares do tráfico}

Nossa história começa quase dois anos antes, em 1837, quando Araújo Lima, Ministro do Império e futuro Marquês de Olinda, um dos principais líderes da maioria parlamentar, subiu à Regência-Una após a convite do renunciante Feijó. Em 22 de abril de 1838, Araújo Lima garantiria sua permanência no cargo, desta vez votado por eleitores do Brasil inteiro, ganhando a disputa contra Hollanda Cavalcanti, candidato da facção dos moderados contrários ao ministério montado depois da renúncia de Feijó. Era a vitória do "Regresso", termo criado por Bernardo Pereira de Vasconcelos, para aquele movimento nascido após a morte de Pedro I que aglutinava a oposição parlamentar a Feijó e que ascenderia ao poder com Araújo Lima na regência provisória. Se a repressão ao tráfico fora tímida nos anos anteriores, agora a omissão seria praticamente política de governo, afagando os grandes produtores rurais. Para os ingleses, o Regresso representava, simplesmente, os traficantes no poder. ${ }^{2}$ Logo no começo do Regresso, Bernardo Pereira de Vasconcelos acumularia as pastas da Justiça e do Império, de onde defenderia a revogação da lei antitráfico e uma posição mais firme contra os ingleses. O tráfico estaria em expansão nos anos seguintes, apesar do Bill Palmerston, de 24 de agosto de 1839, que iria inaugurar uma nova era na repressão, pois a partir dali a marinha britânica não mais respeitaria a soberania lusitana, aumentando a pressão para que Portugal tomasse medidas mais eficazes contra a saída de cativos de seus territórios em África. ${ }^{3}$

Essas questões têm sido aprofundadas por uma vasta bibliografia que deixou claro que é impossível entender a política parlamentar depois de 1831 sem discutir a tal "lei para inglês ver". ${ }^{4}$ Aliás mal apelidada, afinal de contas

1 SILVA, Daniel Barros Domingues da; ELTIS, David. The slave trade to Pernambuco, 1561-1851. In: ELTIS, David; RICHARDSON, David (eds.). Extending the frontiers: essays on the new transatlantic slave trade database. New Haven: Yale University Press, 2008, p.95-129.

2 CARVALHO, José Murilo (org.). Bernardo Pereira de Vasconcelos. São Paulo: Editora 34, 1999, p.27. BETHELL, Leslie. A abolição do comércio brasileiro de escravos. Brasília: Senado Federal, 2002, p.105, p.107-108. Sobre o período regencial como um todo, veja-se: BASILE, Marcello. O laboratório da nação: a era regencial (1831-1840). In: GRINBERG, Keila; SALLES, Ricardo. O Brasil Imperial. v.2 Rio de Janeiro: Civilização Brasileira, 2008, p.53-119.

3 BETHELL, Leslie. A abolição do comércio brasileiro de escravos, p.195.

4 Sob a condução da questão do tráfico no parlamento, veja-se: RODRIGUES, Jaime. O infame comércio: propostas e experiências no final do tráfico de africanos para o Brasil (1800-1850). Campinas: Editora da Unicamp, 2000. 
ela teve efeitos, e muitos, sobre a história do Brasil, como demonstra uma historiografia que só faz crescer. ${ }^{5}$ Não obstante, há detalhes do contexto do tráfico para Pernambuco naqueles anos ainda pouco explorados. Para ser mais exato, a questão é que Araújo Lima e Hollanda Cavalcanti, adversários na eleição para regente de 1838, eram pernambucanos. Na província, portanto, a eleição de 1838 foi mais do que um embate eleitoral entre diferentes facções da elite imperial, entre "regressistas" e "progressistas", como se dizia na época. ${ }^{6}$ Ali ficaram mais claros os contornos mais ríspidos da política oligárquica local. Hollanda e Araújo Lima foram aliados na adesão à "causa do Rio de Janeiro" em 1822 e combateram a Confederação do Equador em 1824, o que garantiu a ambos o apoio de Pedro I às suas demandas na província. Mas começaram a se distanciar ainda no primeiro reinado, quando Araújo Lima mostrou-se um áulico, enquanto Hollanda bandeouse para a oposição parlamentar, afastando-se do imperador, contribuindo para a abdicação, a "revolução do 7 de abril", como se dizia na época. Antes de ser derrotado por Araújo Lima em 1838, Hollanda fora o segundo candidato mais votado na eleição de Feijó para a regência-una em 1835, o que demonstra o seu prestígio no parlamento e representatividade fora de Pernambuco. Nos meandros das conjunturas locais, o que aconteceu em 1838, portanto, foi uma disputa por posições no aparato estatal abertas depois de 1831. Posições que representavam vantagens clientelares e, consequentemente, econômicas e políticas. A dimensão desta disputa intraoligárquica em Pernambuco não pode ser subestimada.

Feijó indicou Araújo Lima senador por Pernambuco em 4 de junho de 1837. Araújo Lima era então uma das principais lideranças do parlamento. Estudioso, arguto e doutor em Coimbra, participaria de praticamente todas as reformas legislativas do seu tempo. Já regente, aberta outra cadeira no Senado por Pernambuco, em 7 de fevereiro de 1838, Araújo Lima designou Hollanda para o posto. Ainda durante sua regência abriu outra vaga no Senado por Pernambuco. Araújo Lima indicou um irmão de Hollanda, Francisco de Paula Cavalcanti de Albuquerque. Desconhecemos o significado exato desse gesto, mas podemos assumir que representava a reconciliação

5 Veja-se o exemplar da revista Estudos Afro-Asiáticos, organizado por Beatriz Mamigonian e Keila Grinberg (Estudos Afro-Asiáticos, v.29, n.1/2/3, Jan-Dez 2007, passim). AZEVEDO, Elciene. O direito dos escravos: lutas jurídicas e abolicionismo na província de São Paulo. Campinas: Editora da Unicamp, 2010. Veja-se ainda: MAMIGONIAN, Beatriz. A proibição do tráfico atlântico e a manutenção da escravidão. In: GRINBERG, Keila; SALLES, Ricardo (orgs.). O Brasil Império (1808-1889). v.1, Rio de Janeiro: Civilização Brasileira, 2008, p.207-233; PARRON, Tâmis. A política da escravidão no Império do Brasil, 1826-1865. Rio de Janeiro: Civilização Brasileira, 2011.

6 Sobre as eleições para regente, veja-se: BASILE, Marcello. O laboratório da nação; BARMAN Roderick. Brazil: the forging of a nation, 1798-1852. Stanford: Stanford University Press, 1988, cap. 6-7. NEEDELL, Jeffrey D. The Party of Order: the conservatives, the state and slavery in the Brazilian monarchy, 1831- 1871. Stanford: Stanford University Press, 2006, cap.3. Sobre o contexto pernambucano durante a Regência, veja-se: MOSHER, Jeffrey Carl. Political struggle, ideology and state building: Pernambuco and the construction of Brazil, 1817-1850. Lincoln: University of Nebraska, 2008, cap.3-4; CADENA, Paulo H. F. Ou há de ser Cavalcanti, ou há de ser cavalgado: trajetórias políticas dos Cavalcanti de Albuquerque (Pernambuco, 1801-1844). Recife: Universidade Federal de Pernambuco, 2011, cap.3 (História, Dissertação de mestrado). 
entre os Cavalcanti e o regente. Dos irmãos senadores, Francisco de Paula, (futuro Visconde de Suassuna), mais velho que Hollanda (futuro Visconde de Albuquerque), se tornaria uma espécie de Vice-Presidente permanente da província de Pernambuco. Já havia assumido a presidência da província antes do Regresso e assumiria outras tantas vezes depois. Cuidava assim dos interesses provinciais do clã. Como bem mostrou Paulo Henrique Cadena, fazia parte da estratégia familiar até o controle sobre a educação da elite, principalmente da Faculdade de Direito, onde estudou gente como Eusébio de Queiroz (formado em 1832), o futuro "papa saquarema", sob cujo ministério se encerraria o tráfico em 1850. Pedro, o mais novo dos 3 irmãos Cavalcanti que se tornariam senadores, formado em Göttingen, já lecionava lá desde 1830 (tornou-se Senador em 1869). Assim, enquanto os irmãos cuidavam dos negócios na província, no parlamento, Hollanda agia com razoável independência partidária, afinal de contas, antes dos interesses dos saquaremas na corte, ou da oposição parlamentar pulverizada pelas províncias e inconstante no parlamento, estavam as pretensões da família distribuída por Pernambuco, Alagoas e Paraíba. Essa marcante presença da oligarquia no Senado, geralmente com interesses convergentes, mas por vezes dividida, talvez explique o que Joaquim Nabuco chamou de "movimentos excêntricos" de Hollanda na corte. ${ }^{7}$ Completariam essa bancada familiar no Senado, dois primos em primeiro grau, Manoel Caetano de Almeida e Albuquerque (nomeado em 1828) e Francisco de Paula Almeida e Albuquerque (nomeado em 1838), e depois o outro primo de quem falaremos muito aqui, Francisco do Rego Barros (Senador em 1850), presidente da província na época da apreensão do Providência.

Peço perdão por simplificar, mas era o que qualquer livro-texto do segundo grau chamaria de "política oligárquica". No meio do caminho dessas alianças e contra-alianças, que, obviamente, também envolviam casamentos e outros negócios e negociatas, está a conjuntura de 1837/38, o "Regresso", a renovação do tráfico, as discussões em torno do desenho institucional que seria implantado com a lei de interpretação do ato adicional em 1840 e as "leis reacionárias" de 1841-42.8

Além dos ministros saquaremas, como Bernardo Pereira de Vasconcelos, o homem forte do chamado "ministério das capacidades", de setembro de 1837, havia um grupo mais doméstico de apoio a Araújo Lima, que ascenderia após a saída de Bernardo. Eram os pernambucanos Maciel Monteiro e Sebastião do Rego Barros. Este último, irmão do presidente de

7 NABUCO, Joaquim. Um estadista do Império. v.1, Paris: Garnier, 1897, p.39

8 CADENA, Paulo H. F. Ou há de ser Cavalcanti, ou há de ser cavalgado. Sobre os Cavalcanti, veja-se ainda MOSHER, Jeffrey Carl. Political struggle, ideology and state building. Estudando a nobreza brasileira, Eul-Soo Pang concluiu que, se os Braganças tivessem decidido formar uma nova dinastia através de casamentos com o patriciado brasileiro, nenhum clã teria mais pedigree do que os Cavalcanti de Albuquerque do Nordeste. PANG, Eul-Soo. In pursuit of honor and power: noblemen of the Southern Cross in Nineteenth Century Brazil. Tuscaloosa: University of Alabama Press, 1988, p.75. 
Pernambuco designado por Araújo Lima. Ainda circularia pelos ministérios do Regresso um terceiro pernambucano, Lopes Gama, nomeado senador pelo Rio de Janeiro por Araújo Lima em 1839. Aliás ao passar por cima de José Clemente Pereira, o sogro de Eusébio de Queiroz, e escolher um pernambucano politicamente acanhado como Lopes Gama para senador pelo Rio de Janeiro, Araújo Lima confrontou os saquaremas, provocando a renúncia do "ministério das capacidades", onde Bernardo havia acumulado as pastas do Império e Justiça. Lopes Gama era irmão do outro Lopes Gama, o padre e cronista liberal moderado mais conhecido pelo nome do seu jornal, o Carapuceiro, do qual falaremos mais adiante. Araújo Lima fora ministro pela primeira vez ainda no primeiro reinado. Manteve-se um áulico, tanto que, enquanto regente, beijou a mão do menino Pedro II na rua, para que todos vissem. Enquanto regente, precisava do apoio dos saquaremas no parlamento. Mas ele não era exatamente um saquarema, tanto que os desafiou frontalmente ao nomear Lopes Gama senador pela província mais importante do reino. Araújo Lima nunca deixou de velar por suas bases locais nas províncias do norte. ${ }^{9}$ Durante o julgamento do Providência, Lopes Gama era o ministro dos Negócios Estrangeiros do governo que sofria um fogo amigo dos saquaremas no parlamento.

Para a presidência de Pernambuco, em 1837, Araújo Lima designou o futuro Conde e senador Francisco do Rego Barros, seu maior aliado na província. Rego Barros, como vimos, era também primo dos irmãos Cavalcanti. A partir dali, portanto, fazia realmente sentido a quadrinha dos praieiros: em Pernambuco ou se era Cavalcanti ou cavalgado. De inusitado na presidência de Rego Barros, sua duração. Salvo uma breve interrupção, quando o irmão Cavalcanti de sempre o substituiu, foram quase sete anos de mandato, encerrado no começo do "quinquênio liberal", em 1844, uma outra história longa que vai desaguar na Insurreição Praieira em 1848/49.10

Talvez seja redundante dizer - mas, às vezes também não faz mal ser um pouco redundante-que essas famílias advinham da grande propriedade rural e estavam vinculadas ao comércio de grosso trato e ao tráfico atlântico de escravos nem que fosse através de casamentos e laços de compadrio.

É aqui que inserimos nesta narrativa José Thomaz Nabuco de Araújo, outra figurinha carimbada da política imperial, cuja vida foi assoberbada na biografia escrita por seu filho, Joaquim Nabuco. Apesar do tom laudatório - natural para um filho-autor - Um Estadista do Império ainda é referência obrigatória para os interessados na História do Império. ${ }^{11}$ Filho de um senador vinculado ao Regresso, Nabuco de Araújo, recém-formado em Olinda,

9 BARMAN Roderick. Brazil; NEEDELL, Jeffrey D. The Party of Order, p.82-86. Veja-se ainda MATTOS, IImar Rohloff de. O tempo Saquarema. São Paulo: Hucitec, 2004, p.152, p.158.

10 MOSHER, Jeffrey Carl. Political struggle, ideology and state building, p.141-145.

11 Como bem disse Jeffrey Needell, o livro de Joaquim Nabuco é, ao mesmo tempo, "indispensable and undependable". NEEDELL, Jeffrey D. The Party of Order, p.200. 
tornou-se promotor do crime do Recife em abril de 1836, iniciando assim sua carreira na burocracia imperial. Depois foi juiz, deputado, ministro, senador e conselheiro de Estado. Exemplifica bem aquele modelo-padrão de carreira da elite imperial traçado por José Murilo de Carvalho. ${ }^{12}$ Durante o governo (1837-44) de Francisco do Rego Barros, ele começou a se destacar na imprensa a favor do "partido da ordem" em Pernambuco. Aliás, já escrevia a favor do conservadorismo liberal desde os tempos de estudante segundo seu filho, Joaquim Nabuco, que disse ainda que seu pai era "íntimo" de Francisco de Paula, o irmão de Hollanda, o que o deixou numa situação desconfortável diante de Rego Barros, quando Hollanda candidatou-se a regente contra Araújo Lima. Mas, como vimos, a conciliação foi rápida na província, pois Araújo Lima nomeou dois irmãos Cavalcanti senadores por Pernambuco. Os vínculos clientelares, elásticos por sinal, de Nabuco de Araújo para com a oligarquia foram bem delineados por seu filho e biógrafo: "entre Suassuna (o apelido do Cavalcanti mais velho) e Rego Barros, a sua dedicação era pelo primeiro; a sua razão política estava com o segundo". ${ }^{13}$

Nabuco de Araújo ainda contraiu o que Jeffrey Needell chamou de um "casamento brilhante", em 1840, com uma sobrinha do Marquês do Recife, Francisco Paes Barreto. ${ }^{14}$ Abastado proprietário, depois de aderir a 1817 junto aos Cavalcanti, bandeou-se para o lado do príncipe regente durante a Independência, liderando a adesão de Pernambuco à chamada "causa do Rio de Janeiro" e a oposição à Confederação do Equador. Por seus serviços à coroa, ganhou um marquesado. Sob tantas mãos protetoras, Nabuco de Araújo foi parar no Parlamento em 1843. Durante o domínio "praieiro" (184548), escreveu nas folhas "guabirus" (os conservadores de Pernambuco) acusando os praieiros dos mais variados crimes, inclusive de contrabandear cativos africanos... a mesma acusação que os praieiros faziam aos guabirus. Ironias à parte, nisso praieiros e guabirus diziam a verdade. Ao final da Insurreição Praieira, Nabuco de Araújo aceitou ser o juiz que instruiu o processo contra os rebeldes. Embora logo anistiados por Pedro II, os réus foram condenados à pena máxima. Como recompensa por seus serviços ao "castelo gótico Rego Barros-Cavalcanti", na sarcástica expressão dos praieiros, sua carreira decolou. Voltou muito prestigiado ao parlamento na legislatura de 1850. Em 1851, finalmente ingressaria na fina elite imperial ao ser nomeado Presidente da dinâmica província de São Paulo.

Nabuco de Araújo alcançaria maior projeção no "Gabinete da Conciliação", liderado por Honório (Marquês do Paraná), quando propôs o decreto 731/1854, mais conhecido como Lei "Nabuco de Araújo", que ampliava a

12 CARVALHO, José Murilo de. A construção da ordem: a elite política imperial. Rio de Janeiro, Campus, 1980, passim.

13 NABUCO, Joaquim. Um estadista do Império, p.38-39. Sobre a disputa interna em Pernambuco entre os Cavalcanti e Araújo Lima, veja-se: CADENA, Paulo H. F. Ou há de ser Cavalcanti, ou há de ser cavalgado, cap.3, passim.

14 NEEDELL, Jeffrey D. The Party of Order, p.181. 
competência da auditoria de marinha para processar os envolvidos no tráfico mesmo depois do desembarque "qualquer que seja a distância da costa em que eles se achem". Resumindo: a jurisdição da auditoria da marinha alcançaria o litoral e seu interior imediato. A partir dali, as autoridades locais não poderiam mais alegar que não era de suas respectivas alçadas perseguir a tripulação e apreender os "africanos livres" que porventura escapassem da marinha brasileira e britânica em mar aberto. ${ }^{15}$ Ao ampliar o leque da punibilidade, a Lei Nabuco de Araújo contribuiria para aniquilar a esperança de renascimento do tráfico. Foi de sua autoria também a primeira minuta do projeto que redundaria na Lei do Ventre Livre. ${ }^{16}$

O que Joaquim Nabuco não disse - e talvez nem soubesse - foi que, no começo da carreira de promotor, o seu pai engajou-se nos casos dos desembarques dos negreiros Rápido e Bom Sucesso em 1837. ${ }^{17}$ Instigado pelo presidente da Província, ainda investigou uma correspondência publicada no Diário de Pernambuco em 1837 defendendo o tráfico e, em 1839, ofereceria a denúncia contra os traficantes envolvidos no caso do Providência, aqui estudado. ${ }^{18}$ Sua tarefa não era fácil. A maioria parlamentar, liderada por Bernardo Pereira de Vasconcelos, apoiava o tráfico e, em Pernambuco, era imenso o poder dos senhores de engenho do litoral que foram paulatinamente transformando os portos naturais em pontos de "desova", como se dizia na época, de navios negreiros. Ao se associarem aos traficantes, aqueles que controlavam o acesso aos melhores portos naturais tornaramse eles mesmos "senhores de engenho traficantes", digamos assim. Como reconheceu o próprio Nabuco de Araújo em um panfleto que escreveu em 1847, até os Cavalcanti recebiam negreiros nos seus engenhos do litoral. ${ }^{19}$

Tal como no resto do império, o tráfico diminuiu logo depois de 1831. Peter Eisenberg argumentou que, em Pernambuco, isso não ocorreu somente devido a uma possível abundância de mão de obra resultante da expansão do tráfico antes de 1831, mas, principalmente, por causa da Cabanada (1832-35) que acarretou uma queda de 25\% nas exportações pernambucanas de açúcar. ${ }^{20}$ Finda a Cabanada, o tráfico voltou a crescer, mantendo-se alto até 1842, quando entrou em declínio, salvo um pico conjuntural depois da lei antitráfico de 1850. Em 1836, dizia o cônsul lusitano

15 Decreto n. 731 de 5 de junho de 1854. Site do Senado Federal, http://www.senado.leg.br/. Acesso em: 10 fev. 2013. BETHELL, Leslie. A abolição do comércio brasileiro de escravos, p.385, p.419 e passim.

16 PENA, Eduardo Spiller. Pajens da casa imperial: jurisconsultos, escravidão e a lei de 1871. Campinas: Editora da UNICAMP, 2001, p.37.

17 MINISTÉRIO PÚBLICO DE PERNAMBUCO. Promotores públicos: o cotidiano da defesa da legalidade, transcrição de documentos manuscritos (1832-1843). Transcrição coordenada por Vera Lúcia Costa Acioli. Recife: Procuradoria Geral da Justiça/Arquivo Público Estadual, 1999, v.1, p.99.

18 MINISTÉRIO PÚBLICO DE PERNAMBUCO. Promotores públicos, v.1, p.180.

19 NABUCO DE ARAÚJO, José Tomás. Justa apreciação do predomínio praieiro ou história da dominação da praia (Recife, 1847). Recife: Secretaria de Educação e Cultura, 1977, p.9.

20 EISENBERG, Peter, Modernização sem mudança. Rio de Janeiro: Paz e Terra, 1977, p.172. 
no Recife que o tráfico era feito "a face das autoridades". ${ }^{21}$ Em 9 de maio de 1837, o cônsul inglês declarou que um "respeitável brasileiro", envolvido no tráfico antes de 1831, disse que, naquela época, os cativos eram adquiridos na África por 12 mil réis e vendidos no Brasil por 150, mas em maio de 1837, eram comprados por 70 e vendidos por 400 mil réis. ${ }^{22} \mathrm{Em}$ outubro do mesmo ano, segundo o mesmo cônsul, o mercado estava tão saturado, que os recém desembarcados estavam sendo vendidos por 250, até 200 milréis, causando prejuízo aos traficantes. ${ }^{23}$

Essa naturalidade do tráfico foi justamente o assunto de uma "correspondência" no Diário de Pernambuco, enviada pelo presidente da província a Nabuco de Araújo, em 1837, para que abrisse processo. ${ }^{24}$ Em um texto sarcástico, o autor anônimo pretendia desmascarar "hipócritas philantropos", como José Bonifácio, que teriam apelidado os negociantes de escravos de "traficantes de carne humana e outros termos da moda". E no entanto, argumentava: "que seria dos brasileiros se não fossem os escravos?" Para o missivista, o tráfico estava tão rotinizado que, deitado numa rede, viu passar em frente à porteira de sua casa uns 40 homens armados, trazendo uns 200 "colonos" africanos. Valiam uma pequena fortuna, tanto que numa praia ali perto houvera uma outra "desova" de um navio, no qual morreram uns "sessenta e tantos" por terem viajado muito "apinhados". Todos receavam adquiri-los, temendo estarem "empestados". Mesmo assim, foram vendidos por 300 a 400 mil réis cada, valor este que confere com a citação acima do cônsul inglês no começo daquele ano. Para o missivista, a escravidão amolecera de tal forma que já se fora o tempo em que os brasileiros "deixavam seus filhos contraídos das donzelinhas africanas jazerem na escravidão, o mesmo não acontece hoje, em que as idéias mais exageradas acerca dos deveres sociais, tal não consistem [sic]". ${ }^{25} \mathrm{O}$ autor assinou-se "Anjo Gabriel". Diante do anonimato e da falta de testemunhas, o promotor Nabuco de Araújo respondeu ao presidente dizendo que aquela carta não era suficiente para indiciar ninguém. ${ }^{26}$

Mas os desembarques feitos pelo brigue Rápido e pelo patacho Bom Sucesso permitiriam a Nabuco de Araújo agir com mais rigor, pois eram dois conhecidos negreiros. Vale salientar que, de todos as embarcações

21 Lisboa. Arquivo Nacional da Torre do Tombo (ANTT), Joaquim Baptista Moreira ao Conde de Vila Real, Ministro e Secretário d'Estado dos Negócios Estrangeiros, 24/09/1836, Correspondência consulados portugueses, Pernambuco, caixa 308.

22 Londres. Parliamentary Papers (PP), Correspondence with British Commissioners and with foreign powers relative to the Slave trade [class A and Class B], v.15. Consul Watts a Mr. Hamilton, 09/05/1837, Third enclosure in number 84 , Class B - Correspondence with foreign powers relating to the Slave trade, 1837, p.76.

23 Londres. Accounts and Papers (Slavery) (APS), Session 15 november 1837-16 August 1838, v.L.PP, Consul Watts a Mr. Hamilton, 27/10/1837, Third enclosure in number 50, Class B (Further Series) - Correspondence with foreign powers relating to the Slave trade, 1837 p.43-44

24 MINISTÉRIO PÚBLICO DE PERNAMBUCO. Promotores públicos, v.1, p.100-101.

25 Diário de Pernambuco, Recife, 17/04/1837.

26 MINISTÉRIO PÚBLICO DE PERNAMBUCO. Promotores públicos, v.1, p.100-101. 
suspeitas de tráfico, a que mais visitou o Recife naqueles anos foi o Bom Sucesso. Foram sete viagens, desde 1831 até sua captura pelos ingleses em 1844. ${ }^{27}$ Isso mesmo se desconsiderarmos uma outra embarcação que tinha o mesmo nome, que naufragou propositalmente em Ponta de Pedras (PE), em 1834, depois de desembarcar 300 pessoas. ${ }^{28} \mathrm{O}$ consignatário do Bom Sucesso, em 1837, era Gabriel Antonio, um dos traficantes mais emblemáticos de Pernambuco. ${ }^{29}$ Aliás, o Bom Sucesso naufragado em 1834 também era dele. Segundo o cônsul português no Recife, em 1835, Gabriel Antonio era o "principal chefe destas empresas de contrabando" (de escravos) na província. ${ }^{30} \mathrm{O}$ proprietário do Bom Sucesso em 1837 era o conhecido traficante angolano Innocencio Mattoso de Andrade Câmara. Nabuco de Araújo, todavia, não encontrou elementos suficientes para indiciar ninguém no caso do Rápido, mas apenas os envolvidos com o Bom Sucesso, pois a única evidência contra o Rápido era carregar uma quantidade de água excessiva para as necessidades da tripulação. ${ }^{31}$

Há muito se sabia que era possível identificar um navio negreiro através de indícios óbvios, como correntes, grilhões, escotilhas gradeadas, o cheiro de morte e excrementos, ou simplesmente o excesso de pipas e barricas de água como no caso do Rápido. Em julho de 1835, Alves Branco assinou um termo aditivo aos tratados com a Inglaterra que antecipavam a chamada "cláusula de equipamentos" de 1839, pois o termo reconhecia como sinais de tráfico, a presença de diversos apetrechos, inclusive "aguada" e víveres além do que precisava a tripulação. ${ }^{32}$ Esse termo, obviamente, nunca foi ratificado pelo parlamento brasileiro haja vista a posição prótráfico da maioria parlamentar. Todavia, em 10 de dezembro de 1836, regras semelhantes entraram na legislação lusitana. Embora o tráfico a partir dos territórios ultramarinos portugueses estivesse proibido havia mais de uma década, foi o decreto de 1836 que permitiu à marinha portuguesa apreender embarcações lusitanas mesmo sem cativos a bordo, desde que houvesse os indícios de tráfico listados na lei. ${ }^{33}$

27 ANTT, Comissão Mista em Luanda, "Relatório dos casos julgados pela comissão mista portuguesa e britânica estabelecida em Loanda no ano de 1844", 31/12/1844. Angolana. Lisboa, Centro de Estudos Históricos Ultramarinos, 1976, v.3, p.615

28 ANTT, Ministério dos Negócios Estrangeiros, Correspondência consulados portugueses, Pernambuco, caixa 308, Joaquim Baptista Moreira a Joaquim Barroso Pereira, Cônsul Geral de Portugal, 14/08/1835.

29 ANTT, Ministério dos Negócios Estrangeiros, Correspondência consulados portugueses, Pernambuco, caixa 308, Joaquim Baptista Moreira ao Ministério dos Negócios Estrangeiros 07/01/1837.

30 ANTT, Ministério dos Negócios Estrangeiros, Correspondência consulados portugueses, Pernambuco, caixa 308, Joaquim Baptișta Moreira a Joaquim Barroso Pereira, Cônsul Geral de Portugal, 14/08/1835.

31 MINISTÉRIO PÚBLICO DE PERNAMBUCO. Promotores públicos, v.1, p.99.

32 Inglaterra e Brasil - Trafego de Escravos - por um Deputado. Rio de Janeiro: Typographia do Brasil de Justiniano José da Rocha, 1845, p.57-58, p.114-115. Sobre a cláusula de equipamentos, veja-se ainda: REIS, João José; GOMES, Flávio dos Santos; CARVALHO, Marcus J. M. de. O Alufá Rufino: tráfico, escravidão e liberdade no Atlântico Negro (c.1822 - c.1853). São Paulo: Companhia das Letras, 2010, cap.13.

33 ANTT, Ministério dos Negócios Estrangeiros, Correspondência consulados portugueses, Pernambuco, caixa 308, Joaquim Baptista Moreira ao Visconde de Sá da Bandeira, Ministro e Secretário d'Estado dos Negócios Estrangeiros, 06/04/37, "Decreto de 10/12/1836", Ministério dos Negócios Estrangeiros (Lisboa): Correspondência das 
A partir do Bill Palmerston (1839), a Inglaterra começou a aplicar unilateralmente essas regras, através da chamada "cláusula de equipamentos", passando a capturar navios que tivessem apenas indícios de tráfico. ${ }^{34} \mathrm{~A}$ lei antitráfico lusitana de dezembro de 1836 foi publicada no Recife pelo consulado português em março de 1837. Como vimos, o parágrafo 5 identificava como indício de tráfico a presença de mais água potável do que precisava a tripulação. ${ }^{35}$ Ora, qualquer pessoa de bom senso perceberia que não se justificava que inúmeros navios viessem da África sem nada no porão a não ser pipas e barris de água. Não havia como pagar uma viagem tão longa apenas com o tal "lastro de aguada", como diziam. $\mathrm{Na}$ realidade, desembarcavam os cativos em alguma praia e depois seguiam para a cidade para preparar o barco e a documentação para outras viagens. Quando o navio ia parar em alguma cidade diferente do que indicava seu passaporte, alegava-se "arribada forçada", ou seja, alguma avaria ou outro problema qualquer que justificasse o desvio da rota. Muitas embarcações atracariam nas capitais brasileiras nessas circunstâncias depois de 1831 . Para completar o disfarce, as pipas de água doce não consumidas eram esvaziadas e preenchidas com água do mar no final da viagem, a pretexto de "lastro de aguada". Com aquela ironia que sempre caracterizou seus escritos, o padre Lopes Gama, que, como vimos, era irmão do ministro homônimo Lopes Gama, comentou em 1837 que o tráfico de escravos havia realmente terminado. Todavia, não faltavam escravos à venda, graças aos talentosos "chimicos" [sic] brasileiros que eram capazes de transformar pipas de água salgada em "negros novos". ${ }^{36}$

Como vimos, Nabuco de Araújo não encontrou elementos para proceder contra os envolvidos nos negócios do Rápido, mas apenas contra os indiciados no caso do Bom Sucesso. Como não encontramos esses processos, não sabemos seus detalhes, mas certamente nada de muito grave ocorreu com os traficantes, pois o Bom Sucesso, que foi indiciado, reapareceria nos anos seguintes no Recife do mesmo jeito, ou seja, sem nada no porão além da tal água mágica de Angola, e com traficantes notórios como proprietários ou consignatários. Três meses depois da sua apreensão, o barco já estava pronto para voltar a África. O proprietário, Francisco José de Magalhães Basto e o consignatário, Gabriel Antonio, eram dois dos indiciados por Nabuco de Araújo. ${ }^{37}$ O Bom Sucesso, portanto, não foi considerado presa

caixas, Papéis Relativos a Escravatura, 1815-1846. Angolana. Lisboa, Centro de Estudos Históricos Ultramarinos, 1976, v.3, p.99.

34 BETHELL, Leslie. A abolição do comércio brasileiro de escravo, p.128; RODRIGUES, José Honório. Brasil e África: outro horizonte. Rio de Janeiro: Nova Fronteira, 1982, p.194-195.

35 Diário de Pernambuco, Recife, 21/03/1837.

36 O Carapuceiro, Recife, v.2, n.36, 19/08/1837. Destilando sua fina ironia nas páginas d’O Carapuceiro, Lopes Gama ficou conhecido como o padre Carapuceiro. Sobre suas ideias, veja-se: FELDMAN, Ariel. Espaço público e formação do Estado Nacional brasileiro: a atuação política do Padre Carapuceiro (1822 a 1852). São Paulo: Universidade de São Paulo, 2013 (História, Tese de doutorado)

37 Diário de Pernambuco, Recife, 06/04/1837. 
justa, nem desapropriado pela justiça brasileira, tanto que reapareceu no Recife, em janeiro de 1838, com 64 pipas de água no porão. O dono agora era o traficante angolano Innocencio Mattoso de Andrade Câmara e Gabriel Antonio, o consignatário dos porões cheios da tal água que se transformava em "negros novos". Um ano depois, em janeiro de 1839, estava novamente no Recife, preparando-se para voltar a Luanda, com o mesmo proprietário e consignatário. A não ser que os químicos brasileiros fossem realmente tão talentosos como dizia o padre Lopes Gama, o Bom Sucesso era um notório navio negreiro. ${ }^{38}$ Mas sem africanos a bordo, na década de 1830, era difícil condenar um navio negreiro.

O dono do Bom Sucesso, Gabriel Antonio, merece algumas linhas por ter sido uma figura emblemática do tráfico pernambucano. Através dos jornais, sabemos que, em janeiro de 1829, ele saiu do Recife para Angola como mestre e caixa do brigue General Silveira, que pertencia a Elias Coelho Cintra, outro notório traficante que, antes de 1831, costumava marcar seus cativos com um "E". ${ }^{39}$ Elias teve um navio apreendido ainda em 1821, por desobedecer os tratados de 1815 que proibiam o comércio atlântico de escravos ao norte da linha equatorial. O brigue Gavião levava papéis para pegar 357 cativos em Cabinda, passando por São Tomé e Príncipe, mas terminou indo parar em Calabar-velha (então sob a soberania de Bonny) onde foi apreendido com escravos a bordo. ${ }^{40}$ Em dezembro de 1829, Gabriel Antonio chegava ao Recife como mestre do brigue Triumpho do Brasil, também de Elias Coelho Cintra. Trazia 507 cativos. ${ }^{41}$ Com o tempo, Gabriel Antonio prosperou, até que deixou de ser mestre de navio negreiro, tornando-se negociante de grosso trato e senhor de engenho. Senhor de engenho traficante, vale ressaltar. ${ }^{42}$

É possível que Nabuco de Araújo não soubesse de alguns dos detalhes sobre o tráfico aqui apresentados, já que não tinha em mãos as fontes portuguesas e inglesas à disposição dos historiadores, que podem, na calma que só o futuro concede, consultar documentos antes sigilosos. Mas, por outro lado, devia saber de outras tantas coisas que não chegaram até nós. Inclusive sobre Gabriel Antonio e seus comparsas. Sejamos mais humildes,

38 Veja-se a correspondência de Joaquim Baptista Moreira ao Ministro dos Negócios Estrangeiros de 07/01/1837, 09/07/37, 26/08/1837, 22/01/1838, 14/01/1839. ANTT, Ministério dos Negócios Estrangeiros, Correspondência consulados portugueses, Pernambuco, caixas 308 e 309.

39 Diário de Pernambuco, Recife, 23/03/1829, 20/01/1829. A embarcação retornaria ao Recife em outubro, trazendo 495 cativos a bordo, afora os 11 mortos na travessia. Estava então consignada a Elias Coelho Cintra, mas Gabriel Antonio já não era seu mestre. Diário de Pernambuco, Recife, 11/10/1829.

40 REBELO, Manuel dos Anjos da Silva. Relações entre Angola e Brasil, 1808-1830. Lisboa: Biblioteca Nacional, 1970, p.24. Rio de Janeiro. Arquivo Histórico do Itamaraty (AHI), Embarcação Gavião, 1820-1829, Comissão Mista (tráfico de negros) Brasil-Grã-Bretanha.

41 Além desses cativos desembarcados, outros vinte morreram na viagem. Diário de Pernambuco, Recife, 05/12/1829

42 Sobre a carreira de Gabriel Antonio, veja-se: CARVALHO, Marcus J. M. de. O "galego atrevido" e "malcriado", a "mulher honesta" e o seu marido, ou Política provincial, violência doméstica e a Justiça no Brasil escravista In: SOHIET, Rachel; BICALHO, Maria Fernanda; GOUVÊA, Maria de Fátima (org.). Culturas Políticas: ensaios de História Cultural, História Política e Ensino de História. Rio de Janeiro: FAPERJ/Ed. Mauad, 2005, p.201-234. 
ele certamente sabia muito mais do que os pobres historiadores imersos em dúvidas, em documentos omissos e cheios de mentiras. O problema de Nabuco de Araújo, todavia, era provar um caso de contrabando de cativos sem que houvesse africanos a bordo em uma época em que a legislação brasileira ainda não condenava navios apenas por estarem equipados para o tráfico. Obviamente, se chafurdasse demais, Nabuco de Araújo talvez terminasse encontrando suspeitos que não queria, ou seja, gente do grupo político do qual dependia.

Como esse tipo de crime ia a júri, havia um segundo problema. Nos anos 1830, dificilmente alguém seria condenado por um delito acobertado por gente poderosa e endinheirada. Que corpo de jurados iria se expor assim a troco de nada? Além disso, entre os próprios jurados poderia haver pessoas envolvidas nos negócios do tráfico que, direta ou indiretamente, empregava muita gente no litoral, seja trabalhando nos desembarques, no aprovisionamento imediato de centenas de pessoas famélicas e sedentas, na vigilância dos desembarcados, em consertos mais simples nos navios e em várias outras atividades secundárias. Jangadeiros e barqueiros iam encontrar os navios em alto mar para guiá-los até os pontos de desembarque e ainda colaboravam com a "desova" quando os navios ancoravam longe das praias. Os arrecifes exigiam ainda práticos locais capazes de entrar na barra em segurança. Na praia, era preciso grande quantidade de frutas da estação e "alimentos frescos", como se dizia na época, para consumo imediato, evitando assim o "mal de Loanda", o escorbuto. Havia ainda gente envolvida na engorda e distribuição da mercadoria humana. Como a propriedade escrava estava bastante pulverizada nessa época, nem todos os desembarcados eram vendidos em grandes grupos, o que atraia inúmeros pequenos compradores. A chegada de um navio negreiro, portanto, era um grande evento no litoral. Em 1852, Eusébio de Queiroz alegou exatamente isso para dizer que, se o governo quisesse, poderia acabar com o tráfico, pois mesmo que os navios negreiros chegassem discretamente, eram tantos os envolvidos nas operações de desembarque, acolhimento e venda dos cativos que era impossível não haver divulgação. ${ }^{43}$ Entre os membros do júri, portanto, podia haver beneficiários do tráfico em diferentes níveis. Acuados, ou coniventes, os jurados terminavam reconhecendo a falta de cativos apreendidos, a evidência do principal crime imputado: a escravização de pessoa livre. E, sem objeto, não há crime. ${ }^{44}$

43 Relatório apresentado à Assembléia Geral, 1852, Center for Research Libraries, Brazilian Government Document Digitalization Project, University of Chicago. Disponível em: <http://brazil.crl.edu/bsd/bsd/660/000005.html>. Acesso em: 10 fev. 2013.

44 Sobre o funcionamento do júri em Pernambuco nesta época, veja-se: PINTO FERREIRA, Augusto César Feitosa. Justiça criminal e tribunal do júri no Brasil imperial: Recife, 1832-1842. Recife: Universidade Federal de Pernambuco, 2010 (História, Dissertação de mestrado). 


\section{Os dois julgamentos do Providência: rotas do tráfico e repressão}

O Providência, denunciado pelo promotor Nabuco de Araújo em 1839, foi apreendido pelo brigue Constança da marinha brasileira, por ordem direta do presidente da província, Francisco do Rego Barros, como vimos, futuro Conde da Boa Vista e Senador do Império, que passaria praticamente sete anos na presidência da província (1837-44), liderando o "partido da ordem" em Pernambuco. ${ }^{45}$ É difícil crer que Rego Barros, um comensal de Araújo Lima, fosse um homem engajado no combate ao tráfico, afinal de contas era um grande proprietário rural e seus parentes e aliados também. Sua família tinha terras a perder de vista na zona da mata, inclusive no litoral onde ocorriam os desembarques. Talvez faça mais sentido atentar para o que disse o pastor metodista Daniel Kidder que passou por Pernambuco nessa mesma época. Ao visitar a ilha de Itamaracá, ele viu um navio negreiro desembarcando cativos calmamente, sem ser importunado e aproveitou para falar da apreensão de um outro negreiro ocorrida um pouco antes, ainda em 1839. Como não houve outro navio capturado em Pernambuco nessa época, podemos assumir com segurança que ele falava do Providência. Kidder contou que o desembarque foi denunciado pelas autoridades provinciais. Mas a embarcação só foi parar em Pernambuco porque vinha fugindo da marinha inglesa. Seu destino original era o Rio de Janeiro. ${ }^{46} \mathrm{Se}$ esta versão procede, foi a perseguição inglesa desde a costa da África que levou o Providência para uma praia errada, digamos assim.

Sabemos que devemos desconfiar dos viajantes, sempre querendo mostrar o exótico, o inusitado e, sutilmente, superioridade diante de povos incivilizados. Será que devemos acreditar que o Providência foi parar em Pernambuco porque vinha sendo perseguido por um navio inglês? A correspondência diplomática inglesa discutiu exaustivamente o caso do Providência. Claro que nem tudo que os ingleses diziam era exato. Erravam e mentiam, como aliás qualquer correspondência diplomática, melhor dizendo, como qualquer fonte histórica. Essa correspondência cala-se sobre a possibilidade aventada por Kidder. Não encontramos menção alguma a uma possível perseguição inglesa. Teria Kidder inventado isso para deleite dos seus leitores? É possível. Mas talvez ele tenha ouvido essa versão através de canais informais - era um pastor ávido por seguidores - conversando aqui e ali, quem sabe com gente direta ou indiretamente ligada aos traficantes, que, nessa época costumavam comprar navios americanos, a mesma nacionalidade de Kidder. Ora, quem estava no Providência certamente teve que explicar por que tanta confusão, por que não foram para a Bahia,

45 MINISTÉRIO PÚBLICO DE PERNAMBUCO. Promotores Públicos, v.1, p.180. ANTT, Pernambuco, caixa 2, 13/08/1839

46 KIDDER, Daniel P. Reminiscências de viagens e permanências nas províncias do norte do Brasil. São Paulo: Itatiaia, 1980, p.119. ANTT, Ministério dos Negócios Estrangeiros, Correspondência consulados portugueses, Pernambuco, caixa 309, Joaquim Baptista Moreira ao Ministério dos Negócios Estrangeiros, 16/09/1839, 
ou Rio de Janeiro, ou mesmo porque foram capturados pela marinha ... brasileira - a menos ameaçadora de todas. O tráfico não era negócio para amadores. Uma perseguição explicaria porque o navio foi avistado sem rumo certo no litoral pernambucano. A favor da versão de Kidder, podemos dizer também que os ingleses perseguiram inúmeros navios desde a África através do oceano, sem saber seu nome, pois apenas vislumbravam uma silhueta ao longe. Muitos escaparam sem serem identificados. É possível que o Providência tenha sido um deles. É relevante ressaltar também que, segundo dados do site slavevoyages, o Providência, no ano anterior, 1838, desembarcou cativos no Rio de Janeiro, justamente o local para onde Kidder disse que o patacho pretendia ir quando foi apreendido em 1839.47 Vale ressaltar que não há indícios de que Kidder soubesse dessa viagem do Providência à corte no ano anterior.

Não quero dizer com isso que os ingleses avisaram as autoridades em terra. Se isso tivesse ocorrido, estaria documentado na correspondência consular, ou então eles mesmos teriam apreendido o navio. Assim se a hipótese de Kidder estiver correta, quem fez a denúncia foi gente de Pernambuco mesmo. Pois, neste caso, a embarcação chegou errante, sem porto certo para desembarcar sua carga humana. Segundo o comandante do Constança e o grosso da correspondência sobre o caso, os cativos foram desembarcados em Itamaracá, perto de onde foi apreendido o Providência. Todavia, existe uma correspondência inglesa indicando que o navio desembarcou 135 pessoas no engenho São João em Pau Amarelo e não em Itamaracá. Como outros negreiros desembarcaram gente em praias pernambucanas naqueles dias e semanas, não podemos afirmar exatamente onde desceram os cativos do Providência. ${ }^{48}$ Mas a menção à praia de Pau Amarelo é valiosa, pois a correspondência sobre o caso, incerta sobre o ponto de desembarque, concorda que o navio perdeu uma âncora naquela praia e porto natural. A sentença do juiz Aguiar também menciona isso. Talvez, portanto, o barco tenha sido avistado da própria fortaleza de Pau Amarelo, que fica em frente à entrada da barra vigiada desde que os holandeses invadiram a capitania em 1630, depois de desembarcar suas tropas justamente ali, longe dos canhões de Olinda, Recife e Itamaracá e de lá seguir pelas largas praias em marche-marche até Olinda. Assim, alguém pode ter visto a embarcação, tateando a costa, esperando saber onde poderia desembarcar em segurança, pois um navio em fuga nem sempre podia ir para onde planejava. A perseguição inglesa obrigou o Providência

47 Disponível em: <http://www.slavevoyages.org/tast/database/search.faces>. Acesso em: 14 abr. 2013.

48 Mr Watts a Palmerston, 27/07/1839 e $2^{\text {nd }}$ enclosure in n.261. In: British Parliamentary Papers, Slave trade. Correspondence with British Commissioners and with foreign powers relative to the Slave trade [class A and Class B], 1840, p. 390-391, p.397. 
a se desviar de sua rota para o Rio de Janeiro e procurar um porto mais perto, no caso, Pernambuco.

É relevante salientar que não era possível aportar em qualquer praia, pois a carga humana poderia ser roubada, quer dizer, "apreendida" pelas autoridades locais. Os cativos eram contrabando. Não havia recurso legal contra quem se apropriasse deles, desde que o apreensor fosse capaz de defender e manter sua posse. Um senhor de engenho, juiz de paz do seu distrito, podia se apossar facilmente dos africanos desembarcados em suas terras sem combinação prévia. No mínimo cobraria uma comissão. Isso se o barco não naufragasse nos arrecifes que atravessam o litoral de Pernambuco. O padre Lopes Gama, o bem humorado irmão do outro Lopes Gama, ministro de Araújo Lima, não se contentou em falar apenas do talento dos "chimicos" brasileiros, capazes de transformar água em "negros novos". Segundo ele, a repressão inglesa era ineficiente, todavia, o tráfico seria extinto devido ao roubo dos cativos, pois no litoral haviam surgido "companhias" que viviam de "saltear por essas praias aos donos das partidas de escravos", tomando os cativos "à força d'armas". ${ }^{49}$

Para evitar um desastre desses, os tripulantes do Providência contataram um notório tráficante local, José Francisco de Azevedo Lisboa, conhecido na praça como "Azevedinho", segundo diria o cônsul inglês alguns anos depois. ${ }^{50} \mathrm{Em}$ 1837, os ingleses apreenderam o contrato de uma firma sediada em Pernambuco cuja única finalidade era trazer gente escravizada da África. Com um capital de 80 contos, a empresa tinha Azevedinho como uma espécie de gerente geral, representando os sócios em todos os empreendimentos. ${ }^{51}$ Foi ele quem providenciou o desembarque do Providência, arranjando os detalhes necessários. Seu trabalho não passou desapercebido, tanto que foi indiciado por Nabuco de Araújo no processo.

Para entrar em uma barra ou ancorar com segurança ao largo, era preciso um piloto que conhecesse bem o local. Essa dificuldade talvez explique o fato do navio ter perdido uma âncora em Pau Amarelo. Navios avistados rondando o litoral, tonteantes, eram, obviamente, negreiros fora de rota. Qualquer navio de carreira rumaria logo para os grandes portos, geralmente nas capitais provinciais, onde havia sinalização adequada e práticos disponíveis para guiar o barco na entrada da barra. E se errasse de rota, seguia para a cidade mais próxima, justamente o que os negreiros

49 O Carapuceiro, Recife, 23/03/1839, p.3.

50 Cowper to Aberdeen, 04/08/1843. In: British Parliamentary Papers, v.26, Correspondence with Foreign Powers, relative to the Slave trade [Class B and C] 1844, n.307, p.364.

51 A correspondência, depoimentos e demais documentos sobre este caso estão em: British Parliamentary Papers, 1839, v.16, Correspondence with British Commisioners and Foreign Powers, Class A and Class B, n.24 (H. W. Macaulay and Walter W. Lewis to Lord Palmerston, 24 de janeiro de 1838) and enclosures, p.15-67. Veja-se ainda: MARQUES, João Pedro. Tráfico e supressão no século XIX: o caso do brigue Veloz. Africana Studia, Porto, n.5, p.155-179, 2002; REIS, João José; GOMES, Flávio dos Santos; CARVALHO, Marcus J. M. de. O Alufá Rufino, cap.10, passim. 
carregados evitavam. Só os negreiros apareciam assim nas localidades costeiras, à espera do momento certo para ancorar e desembarcar. Os ingleses não tinham dúvidas em vigiar os portos menores, principalmente do sudeste. Se o patacho Providência estivesse fugindo deles, uma ótima alternativa seria justamente ir para o litoral de Pernambuco, menos vigiado e mais perto da África do que o litoral sudeste. Isso explicaria também as provas encontradas pela marinha brasileira, indicando que o dono do barco havia se comunicado com negociantes de escravos do Recife. O sujeito que aparecia nos papéis como proprietário do Providência, Nicolao da Silva Chagas, procurou uma conexão local, Azevedinho, para desembarcar sua preciosa carga em segurança. Essa negociação não foi gratuita, pois entre os documentos havia pelo menos dois "credit", segundo os ingleses, assinados no Recife - provavelmente letras de câmbio - pagando os serviços dos contatos em terra. Azevedinho, portanto, ganhou sua comissão.

Há maior concordância nas fontes quanto ao número de pessoas que vieram no navio. Kidder e o cônsul português falaram em 130 cativos. Os ingleses,135. Na denúncia, o promotor Nabuco de Araújo disse que cabiam 150 pessoas nos porões do Providência. O primeiro tenente da marinha brasileira, Hermenegildo Antonio Barboza de Almeida, o oficial que abordou o Providência, encontrou água suficiente para 150 pessoas por mais de 30 dias. ${ }^{52}$ Ora, o patacho era um navio de 90 toneladas. Cabiam mais do que 150 pessoas nele, de acordo com as regras anteriores à proibição do tráfico, que permitiam trazer 5 cativos por cada 2 toneladas. Navios "apinhados", como aquele mencionado pelo "Anjo Gabriel" traziam mais do que isso. Podemos deduzir que, talvez o barco tenha vindo sem completar sua carga. Zarpou com uns 130 ou 150 cativos e pronto. Mas a dedução de Nabuco de Araújo, de que cabiam 150 pessoas em um barco de 90 toneladas, é baseada em uma expectativa excessivamente benévola em relação ao tráfico. E não é preciso nem falar de casos mais grotescos, como do minúsculo Mariquinhas, que com suas 45 toneladas despejou 201 pessoas vivas - não sei como - em uma praia pernambucana em $1843 .{ }^{53}$ Uma viagem mais rotineira, por exemplo, foi a do Tindal (Luendal segundo os portugueses), de 111 toneladas apenas, que desembarcou 260 pessoas no mesmo ano em que veio o Providência. ${ }^{54}$ Os dados do site "Voyages: The Trans-Atlantic Slave Trade Database" apontam para uma viagem bem sucedida de um patacho Providência, de 96 toneladas, em 1838, levando 422 pessoas vivas para Ilha Grande (RJ) de um total de 472 embarcadas

52 Do primeiro tenente do brigue Constança ao comandante do mesmo, 19/7/1839, 4th enclosure in n.168. In: British Parliamentary Papers, Slave trade, v.20. Correspondence with British Commissioners and with foreign powers relative to the Slave trade [class A, B, C and D], 1840, p.309.

$531^{\text {st }}$ Enclosure in n.265, 01/01/1844, Parliamentary Papers. Correspondence with foreign powers relative to the Slave trade [class $B$ and C], v.28, p.411.

$541^{\text {st }}$ Enclosure in n.307, Parliamentary Papers Correspondence with Foreign Powers, relative to the Slave trade [Class $B$ and C] 1844, v.26, p.370. 
em Moçambique. Ora, salvo engano - normal ao se estudar os negócios escusos do tráfico - devia ser o mesmo patacho capturado em Pernambuco no ano seguinte. Relembro aqui que Kidder disse que o Providência ia para o Rio de Janeiro, só foi para Pernambuco por causa da perseguição inglesa. Proporcionalmente, esta viagem ao Rio de Janeiro em 1838, foi tão grotesca quanto a do Mariquinhas para Pernambuco em 1843. ${ }^{55}$

Quanto à rota, Kidder falou que o barco fora aprestado nas ilhas Príncipe. A correspondência consular portuguesa e os documentos apreendidos indicam São Tomé como ponto de partida, mesmo admitindo que o navio teria sido fabricado em Príncipe. ${ }^{56}$ A corrente de Benguela dificultava a viagem dessas ilhas para Angola. Facilitava no sentido contrário. Como o patacho pegou cativos no golfo da Guiné (no rio Benim ou em Bonny como veremos mais adiante), a viagem das ilhas para aqueles pontos da costa da África era fácil, principalmente de Príncipe. Por essa razão, as ilhas tornaram-se entrepostos do tráfico desde o século XVI. Depois de 1831, retomaram importância, pois os navios podiam esperar lá em segurança enquanto os cativos estivessem sendo negociados no Golfo da Guiné. Só partiam depois que as negociações estivessem concluídas e a carga humana pronta para embarcar. Para isso eram avisados por barcos menores que circulavam entre as ilhas e o litoral africano. Assim evitavam esperas mais longas nos portos do tráfico que, além de insalubres para tripulantes europeus e brasileiros, costumavam ser varejados pela marinha inglesa.

Essa rota do tráfico para Pernambuco, ligando as ilhas atlânticas às feitorias para comerciar cativos no golfo da Guiné, ficou explícita quando o Camões e o Veloz, foram apreendidos pelos ingleses em 1837 no rio Benim. Os papéis encontrados no Veloz revelaram as negociações da empresa gerenciada por Azevedinho, tanto em Pernambuco como em mercados africanos sob a suserania do reino do Benim. Como vimos, foi Azevedinho quem providenciou o desembarque do Providência, que, por sua vez, segundo a maioria das fontes sobre o caso, também procedia do rio Benim. Talvez, portanto, o Providência, o Veloz e o Camões fossem da mesma empresa de traficantes. Segundo a documentação apreendida em 1837, os negociantes de Pernambuco que operavam naquela feitoria no rio Benim tinham acesso ao governador das ilhas Príncipe. ${ }^{57}$ Três anos após aquele episódio, em 1840, foi capturada a escuna negreira Flor do Rio, revelando mais uma ponta solta do caso do Providência, ocorrido em 1839. No meio da documentação apreendida na Flor do Rio, havia uma correspondência

55 Voyages: The Trans-Atlantic Slave Trade Database. Disponível em: <http://www.slavevoyages.org/tast/database/ search.faces>. Acesso em: 14 abr. 2013.

56 Joaquim Baptista Moreira ao Presidente da Província de Pernambuco, 07/12/1839, Sixth enclosure to n.168. In British Parliamentary Papers, Slave trade, v.20. Correspondence with British Commissioners and with foreign powers relative to the Slave trade [class $A, B, C$ and $D$ ], 1840, p.311.

57 Veja-se: MARQUES, João Pedro. Tráfico e supressão no século XIX, passim; REIS, João José; GOMES, Flávio dos Santos; CARVALHO, Marcus J. M. de. O Alufá Rufino, cap.10. 
que indicava que o Major Manoel Gomes da Silva, da junta de governo de São Tomé e Príncipe, estava envolvido no caso do Providência. O Major era o dono de uma parte da "carga" enviada para Pernambuco, se é que não era o dono de tudo, desconfiava o oficial inglês que relatou esses detalhes a Lord Palmerston. Nicolao da Silva Chagas, que em Pernambuco se dizia dono do Providência, na realidade, seria apenas o representante do Major Gomes da Silva na empreitada. Em correspondência, Nicolao informou ao Major que entregou para Azevedinho a procuração que Ihe fora enviada. Um ano depois, portanto, Azevedinho continuava vinculado ao caso do Providência. $^{58}$

Fechando essa conexão mercantil ampla, vamos relembrar o brigue Rápido - o tal que, em 1837, Nabuco de Araújo não encontrou elementos para abrir processo. Pois bem, o brigue continuou na rota do tráfico. Ao menos uma vez, em 1838, levou cativos de Onim (atual Lagos) para Pernambuco. Em janeiro de 1839, o cônsul inglês em Cádiz (Espanha) escreveu a Palmerston relatando que o Rápido chegara lá com uma carga de café, trazendo ainda sua proprietária, a Senhora Ferreira, dona de extensas plantações nas ilhas Príncipe, que levou consigo nessa viagem alguns dos seus escravos domésticos. Isso em plena Europa, vale destacar. Dizia o cônsul inglês em Cádiz, que dali o brigue zarparia para levar escravos para Pernambuco. A estratégia para iludir a esquadra inglesa era sofisticada. O Rápido sairia da Europa sem um único apetrecho para o tráfico. Mas enquanto estava em Cádiz, uma "escuna negra", que também pertencia a Senhora Ferreira, coletava cativos em diferentes feitorias na costa ocidental da África, deixando-os nas ilhas Príncipe. Uma vez concluída esta operação, o Rápido zarparia para Príncipe, onde, finalmente seria equipado para o tráfico, transportando a gente escravizada para Pernambuco. ${ }^{59}$

\section{Versões e possibilidades de uma viagem de tráfico}

Como sempre ocorre em negócios ilegais, há várias versões sobre a viagem do Providência. Repito, mais uma vez, que são todas mal contadas, omissas, mentirosas até. Não obstante, prestando atenção aos detalhes, aos enredos, percebe-se as diferentes versões que terminam se completando num mosaico de possibilidades concretas que nos ajuda a entender as rotas do tráfico, as suas estratégias e os seus agentes em diferentes níveis.

58 Outros nomes apareciam na correspondência como parte das conexões atlânticas de Nicolao e do Major, tais como o Senhor Almeida, de Benguela, João Gomez Netto e Companhia e José Dias da Silva e Companhia, do Rio de Janeiro, Caetano José Dias e José de Castro Rezo Mattos, de São Tomé, João Borges da Silva e Venceslao Baptista Gonzales, de Príncipe. Report of the case of the Brigantine "Emilia" alias "Flor do Rio" João José de Santa Anna, Master, Sierra Leone, 14/12/1840. Enclosure in n.111. In: Parliamentary Papers, Accounts and Papers: twenty volumes, Slavery, Session 3 February-12 August, 1842, v.XLII, p.119.

59 Mr. Brackenbury a lorde Palmerston, 01/01/1839, n.83. British Parliamentary Papers, Great Britain, foreign office, Class B Correspondence with Foreign Powers relating to the Slave Trade 1839, p.114. 
A versão dos traficantes está exposta na defesa perante a justiça brasileira. Alegavam que o navio fora fabricado em Príncipe, em julho de 1837, sendo portanto de nacionalidade portuguesa. Na viagem à África, diziam, teria passado por São Tomé, onde recebeu passaporte. Dali deveria ir para o rio Benim pegar azeite, o que justificaria os muitos vasilhames a bordo, seguindo depois para a Bahia, o destino final da viagem. Todavia, alegavam os réus, o proprietário do barco, Nicolao da Silva Chagas, cidadão português, teve uma "retenção de urina", obrigando o Providência a zarpar para o porto mais perto, Pernambuco. Assim, não haveria razão para apreender o navio, pois não havia cativos a bordo, ou seja não havia prova do crime. Além disso, o navio e todos os envolvidos eram portugueses. Escapavam assim, tanto da jurisdição brasileira como da Comissão Mista Brasil-Inglaterra no Rio de Janeiro. Embora esta estória esteja bem justinha e lógica, ela não basta. Há omissões, incoerências e outras possibilidades que merecem discussão.

A maioria dos africanos que veio para Pernambuco nessa época procedia da África centro-ocidental (Congo/Angola). Ocorre que, devido à vigilância inglesa ao sul do equador, alguns traficantes que operavam na província foram buscar cativos mais ao norte, como aliás era a praxe dos negociantes baianos. Os ingleses, os oficiais da marinha brasileira e a maior parte da correspondência consular lusitana indicaram que o Providência viera do rio Benim, o que foi confirmado pela tripulação, que, como vimos, alegava que o navio pretendia carregar azeite de dendê. Mas há uma indicação na correspondência lusitana dizendo que o navio veio de Bonny, outro conhecido porto do tráfico no delta do Niger, mas do lado oposto ao rio Benim. ${ }^{60}$ Pensar que isso é apenas uma confusão semântica, uma inadvertida troca de nomes, parece-me um pouco ingênuo, afinal de contas, o rio Benim e Bonny eram dois importantes e bem conhecidos portos do tráfico. Eram unidades políticas independentes entre si, com elites locais sintonizadas com os negócios atlânticos, que enviaram muita gente para as Américas. Apesar da relativa proximidade, representavam conexões distintas do tráfico e os protagonistas deste episódio estavam todos bem antenados com o tráfico. Não iriam confundir facilmente esses dois portos nessa época. Vejamos isso mais de perto.

Em seus relatos, o comandante do Constança e o oficial que primeiro abordou o Providência não tinham dúvidas de que aquele era um navio negreiro. Encontraram inclusive duas das evidências mais sórdidas do tráfico, o cheiro terrível e marcas de que as escotilhas antes haviam sido gradeadas. Havia ainda um número excessivo de vasilhames que só eram apropriados para água e não para óleo de palma. Segundo eles, o navio

60 ANTT, Ministério dos Negócios Estrangeiros, Correspondência consulados portugueses, Pernambuco, caixa 309, Joaquim Baptista Moreira ao Ministério dos Negócios Estrangeiros, 13/08/1839, 16/09/1839. 
viajou 34 dias desde o rio Benim, deixando sua carga humana em Itamaracá. Falaram do rio Benim por causa dos papéis encontrados no navio. Mas nem os oficiais brasileiros confiavam nesses papéis, pois disseram que o diário de navegação não passava de uma folha suja, escrita a lápis em espanhol, sem qualquer cálculo, ou nada que revelasse a verdadeira rota da embarcação. Isso, ressalte-se, numa viagem de travessia atlântica. Diante de tanta incerteza sobre a rota, talvez, quem sabe, o navio tenha vindo realmente de Bonny e não do rio Benim. Não interessava aos traficantes revelar a real procedência do Providência. Quem sabe, a informação sobre Bonny tenha chegado ao cônsul através de conversas informais com gente da comunidade portuguesa e daí repassada até nós. Seja como for, também era antiga a ligação de Pernambuco com Bonny, como vimos no caso do Gavião acima. ${ }^{61}$

Laureano Marques de Barros, que se dizia mestre da embarcação, apresentou doze documentos no ato de captura. Entre eles, um contrato entre Domingos Valdez e Nicolao, o dono do navio, para trazer cem ou mais "passageiros", por "80 silver dollars" cada. Esses "passageiros" iriam desembarcar na Bahia ou na sua vizinhança. Havia ainda um recibo indicando que Valdez recebera "40 onças" - muito provavelmente de ouro - pelo frete de São Tomé ao Brasil. No Providência havia dois africanos boçais, trazidos por Nicolao, com passaportes de passageiros. Um deles era uma criança. Aliás havia ainda mais um africano boçal incluído no rol de tripulantes. Chamou também atenção um documento, indicando que o salário da tripulação era "exorbitante", nas palavras do comandante do Constança. Segundo ele, salários assim eram típicos de navios de contrabando. Os papéis apreendidos também indicavam que ao menos dois tripulantes mais graduados do Providência receberam como remuneração o direito de transportar "passageiros" consigo. Balthasar Simo cinco. O espanhol Antonio Dias, quatro. O comandante do Constança inclusive desconfiou que o verdadeiro mestre do navio era Antonio Dias, e não Laureano, pois estavam escritas em espanhol as tais folhas sujas entregues à guisa de diário de bordo.

Havia ainda uma correspondência com gente do Recife, indicando que a tripulação passou alguns dias se comunicando com a cidade para poder desembarcar os tais "passageiros". Ora, como vimos, um navio que alcançasse um ponto exato, previamente combinado, não precisaria disso. As praias do tráfico de Pernambuco ficavam nos limites de grandes engenhos que recebiam navios com regularidade nessa época. Contavam com uma estrutura de recepção, com sinais, jangadas para guiar os barcos etc. Essa correspondência sugere, portanto, que o patacho não foi para

61 Veja-se: OLIVEIRA, Cyra Luciana Ribeiro de. Os africanos livres em Pernambuco, 1831-1864. Recife: Universidade Federal de Pernambuco, 2010 (História, Dissertação de mestrado). 
um lugar previamente estabelecido e simplesmente "desovou" os cativos onde eram esperados. Foi preciso entrar em contato com negociantes locais antes de aportar em segurança. O ponto de desembarque foi decidido na chegada, atrasando as operações e consequentemente chamando a atenção daqueles que levaram a notícia ao presidente da província. Duas cartas listadas pelo comandante do Constança faziam menção direta a escravos. Cartas, que, infelizmente, não foram transcritas pelos ingleses. Por último, um documento assinado pela tripulação afirmava que a rota fora alterada por causa da doença do dono. Doença esta que o comandante do Constança não notou. Segundo ele, Nicolao não apresentava nenhum sinal da terrível "retenção de urina" que levou o navio a desviar sua rota para Pernambuco.

O promotor Nabuco de Araújo listou alguns denunciados em seu ofício ao presidente da Província. Entre eles, o Azevedinho, como vimos, um conhecido traficante. Seu nome despertou a atenção da embaixada inglesa no Rio de Janeiro, mesmo depois da absolvição do Providência. ${ }^{62}$ Da perspectiva da promotoria, o envolvimento de negociantes residentes no Brasil seria a prova de que o navio era brasileiro, ou, no mínimo, pertencia a brasileiros adotivos, como se dizia na época, sendo da alçada da justiça pernambucana julgar o caso. Foi com esse argumento que o promotor levou o processo a júri, para ser julgado e sentenciado pelo juiz do crime da comarca do Recife, João José Ferreira de Aguiar.

Bacharel da primeira turma da Faculdade de Direito de Olinda (e colega de turma de Eusébio de Queiroz), o futuro Conselheiro Aguiar e Barão de Catuama (uma das praias do tráfico de Pernambuco) presidiu a Paraíba entre 1837 e 1838. Ora, ninguém iria ser indicado para um cargo desses sem estar em sintonia com o gabinete do Regresso ou ao menos com o regente. Na década de 1840, Aguiar escreveria na imprensa favorável ao presidente Rego Barros e ao partido conservador. ${ }^{63} \mathrm{Em} 1839$, ele considerou os argumentos da defesa mais convincentes. Na sentença disse que os tais "indícios" de tráfico arrolados pelo promotor Nabuco de Araújo não tinham respaldo na legislação brasileira, ou seja, os tais equipamentos não serviam de prova. Era preciso haver testemunhas do desembarque, ou, melhor ainda, a apreensão de "africanos livres" no ato de captura. Todos os argumentos da denúncia foram desmontados pelo juiz. A sentença foi totalmente favorável aos réus. Sarcástica até, pois, escreveu Aguiar, a péssima qualidade do diário de bordo - a tal folhinha suja escrita a lápis, sem

62 George Jackson e Fred Grigg a Palmerston, 22 de maio de 1840, n.176. In: British Parliamentary Papers, Slave trade. Correspondence with British Commissioners and with foreign powers relative to the Slave trade [class A, B, $C$ and D], 1840, v.20.

63 SACRAMENTO BLAKE, Augusto V. A. Diccionario bibliographico brazileiro. Rio de Janeiro: Typographia Nacional, 1895, p.468-469; PEREIRA DA COSTA, Francisco Augusto. Anais Pernambucanos. v.9, Recife: Fundarpe, 1983-1985, p.248-249; VASCONCELLOS GALVÃO, Sebastião. Diccionário chorográfico, histórico e geográfico de Pernambuco (Rio de Janeiro, 1908-1927). v.4. Recife: CEPE, 2006, p 335. 
cálculo algum - era uma falha imperdoável em termos de navegação, mas não configurava crime. O navio foi devolvido aos proprietários.

Foi aí que o presidente Rego Barros interferiu e mandou apreender novamente o patacho. Não fez isso aleatoriamente. Obedeceu um aviso imperial do ministro dos Negócios Estrangeiros, Lopes Gama - o adversário dos saquaremas - que solicitou o envio do navio para ser julgado pela Comissão Mista Brasil-Inglaterra no Rio de Janeiro. Era setembro de 1839. Após reparos, o patacho seguiu viagem, sob protesto do cônsul português e do seu comandante, Laureano Marques de Barros. Ambos argumentaram que o navio já tinha sido absolvido pela justiça pernambucana e que, portanto, era um abuso apreendê-lo novamente. Em resposta, Rego Barros alegou estrita obediência ao aviso do ministro Lopes Gama, seu conterrâneo e aliado. Diante da inépcia do seu governo em face de outros 22 desembarques em Pernambuco em 1839, é claro que havia motivações mais específicas para agir. Como vimos, há sólidos indícios de que o Providência realmente não ia para Pernambuco e que estava vinculado a redes de traficantes de outras províncias - muito provavelmente do Rio de Janeiro, afinal de contas, como vimos, em 1838, o patacho chegou em Ilha Grande "apinhado" de gente de Moçambique. O alvo, portanto, talvez não fosse o tráfico para Pernambuco, mas aquele navio em particular, vinculado a traficantes da corte. Talvez fosse um recado de que nos portos dominados pelo tal "castelo gótico Cavalcanti-Rego Barros" não havia lugar para aventureiros de outras paragens sem prévia combinação. Seja como for, Rego Barros enviou o navio para o ministro pernambucano Lopes Gama que, como vimos, foi ungido por Araújo Lima como senador pelo Rio de Janeiro, o coração do império, atropelando José Clemente Pereira, o candidato dos saquaremas.

$\mathrm{Na}$ corte, Lopes Gama entregou o caso à Comissão Mista BrasilInglaterra. Repetiram-se as alegações das partes. Os traficantes mais uma vez levaram a melhor. Desta vez os argumentos diplomáticos prevaleceram. Concordando com o que dissera o cônsul português, a comissão mista reconheceu que o Providência fora fabricado e embandeirado em terras lusitanas e pertencia a cidadãos portugueses. Não era brasileiro. Fugia assim da jurisdição da comissão Brasil-Inglaterra. Estava encerrado o caso, para lamento de Nabuco de Araújo, de Rego Barros e do juiz inglês na comissão mista que não tinha dúvidas das provas apresentadas pela marinha brasileira. Provas que nada valiam diante da incompetência legal da comissão mista para julgar o caso.

Toda a operação fora em vão. O combate ao tráfico mostrou-se ineficaz diante do peso das circunstâncias legais da apreensão, apesar do esforço de um prestigiado presidente de província e de um ministro da cota pessoal do regente. Realmente, não faltava apoio ao tráfico. Nem o quadro de promotores de Pernambuco estava imune a essa influência, pois um dos colegas de promotoria de Nabuco de Araújo era Elias Coelho Cintra Jr., o 
filho de Elias Coelho Cintra, como vimos, um dos traficantes de escravos mais notórios de Pernambuco, que já era contrabandista antes de 1831, pois teve um dos seus navios negreiros apreendidos pelos ingleses por desobedecer os tratados que proibiam o tráfico ao norte do Equador. ${ }^{64}$

É bastante revelador deste imbróglio diplomático o teor da correspondência consular lusitana sobre o caso. Para implementar a legislação antitráfico lusitana de 1836, os cônsules portugueses foram instruídos pelo Ministro dos Negócios Estrangeiros de Portugal a visitar nos portos brasileiros os navios lusitanos procedentes da África para averiguar possíveis indícios de tráfico. Era tamanha a timidez do cônsul em Pernambuco em denunciar o tráfico que terminou sendo advertido com veemência pelo ministro português, em 1838. O cônsul, Joaquim Baptista Moreira, simplesmente não viu nada suspeito na escuna Livramento, um conhecido negreiro, que chegou da África em lastro e com aguada bem superior às necessidades da tripulação. ${ }^{65} \mathrm{Em} 1839$, Moreira defenderia vigorosamente os envolvidos no caso do Providência. Essas atitudes não surpreendem, pois Joaquim Baptista Moreira era irmão de João Baptista Moreira, o embaixador português no Rio de Janeiro cuja carreira foi enlameada por seu envolvimento com os traficantes daquela praça. ${ }^{66}$ Joaquim também era ligado a traficantes. Sua correspondência deixa claro que um dos seus principais convivas era Ângelo Francisco Carneiro, um abastado traficante de escravos atuante em Pernambuco, que, ao voltar a Portugal depois de 1850, tornou-se Visconde de Loures. ${ }^{67}$ Nas vistorias nos navios suspeitos de tráfico, os cônsules deveriam levar uma testemunha. Em 1842, Joaquim levou consigo ninguém menos do José Francisco de Azevedo Lisboa, pois é, o Azevedinho, o negociante envolvido no caso do Providência, um notório traficante. Não surpreende que os dois amigos não encontraram nada de suspeito no Real Príncipe Dom Pedro. ${ }^{68}$

Talvez inibido pela advertência que levou em 1838, quando o Providência apareceu em 1839, Moreira quis mostrar serviço. Não contra o tráfico, mas a favor dos interesses dos súditos de sua majestade fidelíssima, o rei de Portugal. É aqui o momento culminante de sua correspondência. Moreira

64 MINISTÉRIO PÚBLICO DE PERNAMBUCO. Promotores Públicos, v.1, p.70, p.76, p.266. Veja-se ainda as informações biográficas no CD de SALES DE ALBUQUERQUE, Francisco; ACIOLI, Vera Lúcia Costa (orgs.). Promotores Públicos, o cotidiano em defesa da legalidade. Recife, Ministério Público de Pernambuco, CERPE, 2006.

65 ANTT, Ministério dos Negócios Estrangeiros, Correspondência consulados portugueses, Pernambuco, caixa 308 Joaquim Baptista Moreira ao Ministério dos Negócios Estrangeiros, 02/05/1838.

66 BETHELL, Leslie. A abolição do comércio brasileiro de escravos, p.173; ACCIOLI, Nilma Teixeira. José Gonçalves da Silva à Nação Brasileira: o tráfico ilegal de escravos no antigo Cabo Frio. Niterói: Funarj/Imprensa Oficial, 2012, p.107-111

67 ZÚQUETE, Afonso Eduardo Martins (dir., coord., comp.). Nobreza de Portugal. v.2, Lisboa: Editorial Enciclopedia, 1960, p.699-700.

68 ANTT, Coleção do Ministério dos Negócios Estrangeiros, Pernambuco, Caixa 3, Joaquim Batista Moreira ao Ministério dos Negócios Estrangeiros, 08/11/1842, 15/12/1842. Sobre Azevedinho e os outros traficantes aqui mencionados, veja-se: REIS, João José; GOMES, Flávio dos Santos; CARVALHO, Marcus J. M. de. O Alufá Rufino, cap.10, passim. 
foi um veemente defensor dos réus perante a justiça brasileira e diante da comissão mista. Negou sempre que o Providência fosse um navio negreiro, apesar de todos os indícios em contrário. Todavia, na sua correspondência sigilosa com o ministério dos negócios estrangeiros lusitano, ele disse a verdade. Afirmou que não tinha nenhuma dúvidas de que o Providência era um navio negreiro que havia desembarcado "uns 130 e tantos escravos" ao norte do Recife. A lápis, nesta carta de Moreira, havia um despacho do Ministro mandando que defendesse os súditos portugueses no caso. ${ }^{69}$ Assim, apesar de saber, como aliás todo mundo, que o Providência era um navio negreiro, por "decoro", Moreira não poderia deixar que o Brasil aplicasse a legislação antitráfico ... lusitana, pois não havia tratados entre as duas nações que permitisse isso. ${ }^{70}$ Assim, com a concordância de seus superiores, Moreira defendeu os súditos de Portugal e a dignidade de sua bandeira perante a justiça local, o governo provincial e a comissão mista, mesmo sabendo que o Providência estava infringindo a legislação lusitana.

Essa correspondência sigilosa revela como era importante, da perspectiva da diplomacia lusitana, contestar o direito da marinha e dos tribunais brasileiros, ou mesmo da Comissão Mista Brasil-Inglaterra, de apreender e julgar um navio português. Revela também como era importante resistir contra a diplomacia e a marinha inglesa, capazes de imensas arbitrariedades escudadas numa causa nobre: o combate ao tráfico. A prepotência inglesa era um dos argumentos prediletos dos defensores do tráfico no Brasil. Apesar de todo este imbróglio, o testemunho secreto de Moreira confirma o que todos sabiam: o Providência era um navio negreiro.

Mas se era a função de Moreira defender os interesses de Portugal, cabia ao promotor Nabuco de Araújo denunciar o tráfico e, consequentemente, a escravização de pessoas livres, mesmo que inutilmente. É impossível saber se essa derrota de Nabuco de Araújo teve algum impacto em suas atitudes posteriores como legislador e ministro. Atitudes firmes em relação ao tráfico, mas frouxas quanto à libertação dos africanos livres, cujas cartas de emancipação levavam anos para serem processadas, por vezes devido a decisões dele próprio, como Ministro da Justiça, segundo informou Beatriz Mamigonian. ${ }^{71}$ Não é impossível, todavia, que essa experiência tenha the incomodado, contribuindo para nortear seus passos no combate ao tráfico nos anos seguintes. Sob o ponto de vista legal, a lei Nabuco de Araújo, de 1854, fecharia o cerco contra o tráfico ao retirar da justiça comum o julgamento dos indiciados em terra. Ficava tudo com a

69 ANTT, Ministério dos Negócios Estrangeiros, Correspondência consulados portugueses, Pernambuco, caixa 309, Joaquim Baptista Moreira ao Ministério dos Negócios Estrangeiros, 16/09/1839; ANTT, Pernambuco, caixa 2, 16/09/1839.

70 ANTT, Ministério dos Negócios Estrangeiros, Pernambuco, maço 155, 02/11/1839.

71 MAMIGONIAN, Beatriz Gallotti. To be a liberated african in brazil: labour and citizenship in the nineteenth century. Canadá: University of Waterloo, 2002 (História, Tese de doutorado), passim, principalmente, capítulo 5. 
Auditoria de Marinha, vulnerável à influência do núcleo do poder, mas menos permeável aos interesses dos potentados locais. Nabuco de Araújo não era um abolicionista. Nunca foi. Mas não deve ter gostado da amarga inutilidade de seus argumentos para condenar Azevedinho e outros traficantes em um caso tão óbvio como o do Providência. Ainda mais com o apoio dos seus chefes políticos, Rego Barros e Araújo Lima. Os indícios que apontou na denúncia foram descartados como prova, embora todos soubessem muito bem o que significavam.

E o que teria movido o presidente Rego Barros a mandar a marinha apreender o Providência especificamente entre tantos desembarques naquelas mesmas semanas e meses? Houve pelo menos outros 22 desembarques de navios negreiros no litoral pernambucano em 1839. Mas somente o Providência interessou de fato ao presidente. O cônsul inglês ficou surpreso com sua atitude, agindo com "unusual dispatch" naquele episódio. ${ }^{72}$ Talvez uma das chaves explicativas esteja na conjuntura política. Rego Barros era o principal aliado de Araújo Lima na província. E, como vimos, era primo dos irmãos Cavalcanti. Mas Araújo Lima tinha faixa própria de atuação, tanto na província quanto diante dos saquaremas. Talvez, portanto, a apreensão refletisse a tensão intraoligárquica local. Mas talvez, também respondesse a uma tensão um grau acima na política. Araújo Lima era Regente, mas o homem forte no Parlamento era Bernardo Pereira de Vasconcelos, que saiu do gabinete depois que o Regente atropelou os interesses dos saquaremas do Rio, ungindo Lopes Gama senador por aquela província. No parlamento, Bernardo seria dali em diante uma pedra no sapato de Araújo Lima culminando com a crise parlamentar que abriu caminho para o "golpe da maioridade" em 1840. O grupo mais "doméstico", digamos assim, de ministros, os pernambucanos Maciel Monteiro e depois Lopes Gama (irmão do cronista antitráfico, o padre Carapuceiro) eram contrários ao tráfico, o que não significa que tivessem força para vencê-lo, sequer colocar obstáculos mais efetivos. Nessa conjuntura, portanto, a perseguição ao Providência, talvez fosse um sutil e sinuoso recado a Bernardo, aos saquaremas e aos próprios traficantes sediados no Rio de Janeiro. Não quero dizer aqui que o tráfico estava regionalizado. Pelo contrário, o fato de os mesmos navios visitarem diferentes portos sugere que havia redes interregionais operantes. Todavia, para atuar numa determinada província era preciso contatos prévios bem urdidos. Ao chegar inadvertidamente, o Providência escapou dos acordos locais envolvendo o tal "castelo gótico Cavalcanti-Rego Barros", àquela altura sob a suzerania-mor de Araújo Lima. Isso não seria permitido.

72 Segundo os dados do "Voyages: The Trans-Atlantic Slave Trade Database", em 1837 entraram 6.650 cativos em Pernambuco, em 1838, 5.950, em 1839, 5.250, em 1840, 5.683. Disponível em: <http://www.slavevoyages.org/ tast/database/search.faces >. Acesso em: 14 abr. 2013. 


\section{Nos labirintos do tráfico e da política imperial}

É impossível saber todos os detalhes deste imbróglio, mas ele permite observar algumas questões sobre o tráfico e sobre a política imperial. Praticamente toda a elite imperial estava vinculada ao tráfico, nem que fosse indiretamente. Mas isso não quer dizer que havia uma total coesão dos sucessivos gabinetes do Regresso em relação ao contrabando de escravos. Havia uma tensão em torno do assunto. O tráfico ganhou devido a seu peso econômico brutal. Os que eram contrários perderam, mas não havia total unanimidade quanto à questão, mesmo que a posição antitráfico fosse minoritária. A regência de Araújo Lima precisa ser periodizada. O gabinete caseiro de Araújo Lima não era o mesmo de antes no qual Bernardo Pereira de Vasconcelos reinara. Havia uma disputa pelos espaços de poder entre os novos ministros, mais acanhados, representando oligarquias decadentes, e a maioria parlamentar comandada pelos saquaremas que representavam províncias em ascensão e que, portanto, precisavam de mais mão de obra do que Pernambuco. O mais importante aqui, é perceber que o tráfico podia ser instrumentalizado nessa contenda entre esses aliados pero non tropo, que subiram em 1837 e se dispersaram pouco a pouco abrindo a brecha para o "golpe da maioridade" em 1840.

O combate ao tráfico, muito provavelmente insincero por parte de quase toda a elite imperial, podia servir nas disputas políticas, tanto no plano local como imperial. A apreensão do Providência, portanto, pode também ser entendida como um recado do governo de Rego Barros, com o apoio do regente, aos adversários na política local e imperial, sugerindo que, se o governo desejasse, poderia agir com mais rigor e assim atrapalhar a vida de muita gente na corte ou nas localidades. Não quero dizer que se pretendia reprimir todo o tráfico. Mas é certo que se poderia reprimir a parcela desejada, ou seja, aquela vinculada aos adversários, ou ao menos aos que não pertenciam à mesma rede clientelar e política. O Providência servia esse propósito, pois, pelo que vimos, vinha fugindo dos ingleses com carga consignada a negociantes do Rio de Janeiro e pertencia a estrangeiros. Ou seja, os interesses locais do tráfico não foram atingidos, pois só o navio foi apreendido, os cativos ficaram, depois de pagas algumas comissões aos negociantes locais, como Azevedinho, que saiu do Recife para providenciar o desembarque e ainda atuou como procurador dos negociantes de fora. O prejuízo, o navio em si, foi jogado na conta do traficante que se aventurou em praias onde não era esperado. A rede local cobrou seu preço de negociantes vinculados a outras redes. O regente e seus aliados locais aproveitaram para se mostrar bem mais interessados em reprimir o tráfico do que costumavam ser. O peso econômico do tráfico se impôs. O legalismo na sentença também. E o recado foi dado.

Fica claro também que nada aconteceu de forma linear neste episódio, pois cada instância envolvida jogou seu próprio jogo. Era assim nos 
negócios do tráfico. Vejamos isso mais de perto. O promotor, aliado de proprietários que recebiam negreiros nas praias de seus engenhos, denunciou apenas aquele navio negreiro (entre os 23 que visitaram Pernambuco naquele ano) instigado pelo presidente, parente de donos de praias do tráfico. O caso foi julgado por um juiz do mesmo partido de ambos, que absolveu os indiciados, defendidos pelo cônsul português, que confessou em sua correspondência que não tinha dúvidas de que o Providência era um navio negreiro. O navio foi recapturado pelo presidente que o enviou ao Rio de Janeiro, onde a comissão mista reafirmou que aquele era um navio negreiro, mas se declarou incompetente para julgá-lo. Apesar da abundância de indícios de tráfico, renderam-se às razões do cônsul, o tal que mentia o tempo todo: o navio não era brasileiro e portanto fugia da alçada daquela comissão.

Este quebra-cabeça montado na argumentação das partes envolvidas não é apenas uma curiosidade. É irônico, quase cômico, mas não é irrelevante, pois este complexo e sinuoso enredo representa o universo de possibilidades do tráfico, que não era um negócio linear, com direção única. Era muito mais. Esta é a segunda janela aberta por este episódio: ele permite observar esse universo de alternativas, esse jogo de possibilidades do tráfico. Assim, concluindo e resumindo, o que vimos foi um navio, pertencente a traficantes de escravos portugueses, talvez residentes no Brasil mas que o registraram nas llhas Príncipe, comandado por um português que se dizia mestre da embarcação, ou por um espanhol que parecia sê-lo, que saiu das ilhas Príncipe, ou de São Tomé, embarcou cativos no rio Benim, ou em Bonny, e zarpou em direção ao Rio de Janeiro, ou talvez para a Bahia, mas foi parar em Pernambuco, talvez porque o suposto dono realmente estivesse enfermo, talvez porque era para Pernambuco que o navio realmente pretendia ir, mais provavelmente porque vinha fugindo da marinha inglesa e desviou sua rota original para o Rio de Janeiro indo para um local menos vigiado e mais perto. O patacho perdeu uma âncora em Pau Amarelo, onde descarregou sua preciosa carga humana, ou seguiu para a ilha de Itamaracá, mais ao norte, e foi lá que os cativos desembarcaram. Confuso, não? Mas isso é um mosaico de possibilidades concretas. Qualquer uma delas poderia acontecer, ou aconteceu, com diferentes navios da rota do tráfico, que envolvia redes diversas, por vezes superpostas, às vezes tenuamente interligadas. De certo mesmo, sabemos que o Providência foi mais um navio negreiro que desembarcou cativos em Pernambuco. Sua apreensão revelou ainda que o tráfico estava bem organizado na província, mas que havia uma tensão entre os aliados de Araújo Lima. Tanto em Pernambuco como na corte, ainda não havia uma total sintonia quanto ao tratamento que deveria ser dado ao problema. Mas, caso o governo desejasse, seria possível uma repressão seletiva, em terra ou no mar, protegendo aliados, prejudicando adversários. A repressão podia ser instrumentalizada no jogo 
do poder. Somente em 1846, é que outro navio negreiro seria capturado em Pernambuco. Mas o Bom Jesus naufragou. A Clementina, em 1831 e o Despique em 1832, arribaram danificados. No oceano, antes da lei antitráfico de 1850, somente o patacho Providência. 